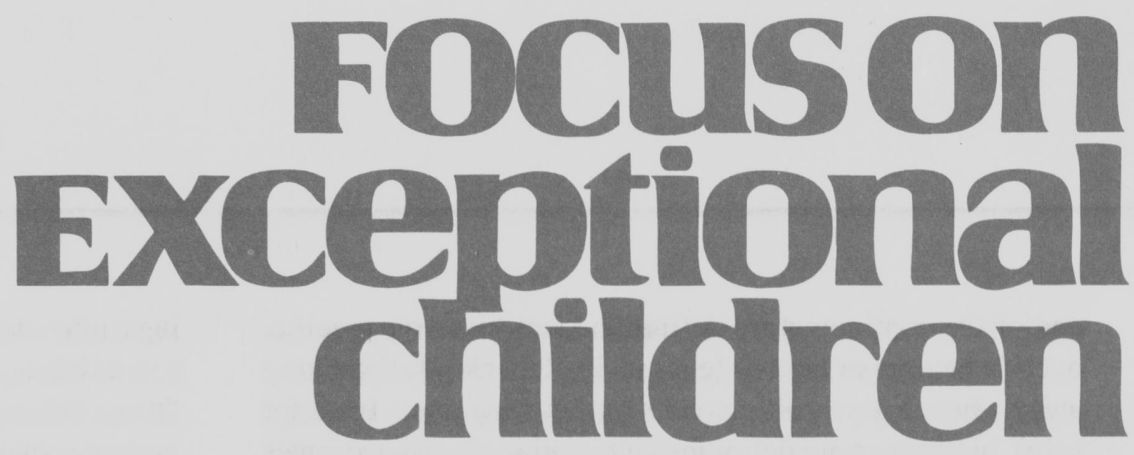

\title{
Preferred and Promising Practices for Social Skills Instruction
}

\author{
George Sugai and Timothy J. Lewis
}

Teaching children and youth to be socially competent is a central theme within schools. As Odom, McConnell, and McEvoy (1992) stated, "Humans enter a social world at birth and make their way through the world by successfully negotiating decades of social exchange" (p. 7). An estimated $10 \%$ of school-age children, however, have social skill difficulties significant enough to lead to peer rejection (Asher, 1990). For children with disabilities, the problem is even worse. Early education teachers have indicated that up to $75 \%$ of children with disabilities need remediation in social skills (Odom et al., 1992). Teaching social skills directly is one strategy to provide children with the social behaviors they need to successfully interact socially with peers with and without disabilities (Hops, Finch, \& McConnell, 1985).

Most published social skills curricula fail to meet the specific needs of students with disabilities and lack information about assessment, teaching, and generalization strategies (Maag, 1989). The need for effective social skills curricula is highlighted by teacher surveys that overwhelmingly indicate that special and regular educators alike believe social skills training should be an integral part of the curriculum (Bain \& Farris, 1991; Fuller, Lewis, \& Sugai, 1995; Meadows, Neel, Parker, \& Timo, 1991).

The focus of this article is on the strategies and structures necessary for fostering social competence in all children, and, in particular, children who are at risk of academic or social failure. These include strategies for assessing and understanding social skills problems, strategies for teaching social skills, and preferred practices for achieving generalized responding. Guidelines for developing, examining, and selecting a social skills curriculum are provided.

\section{CLARIFICATION OF TERMS}

\section{Social Competence}

If a dozen individuals were asked how they would define social competence, 12 different definitions would likely emerge. The professional literature provides a variety of overlapping definitions (e.g., Elliott \& Gresham, 1991; Gresham, 1986; Hollinger, 1987; Maag, 1989; Walker, McConnell, Holmes, et al., 1983). At one end of the continuum, definitions of social competence focus on large attributes (e.g., empathy, cooperativeness, sensitivity), which tend to be "owned" by or associated specifically with the child or youth. At the other

Dr. Sugai is an associate professor in the Department of Special Education and Community Resources at the University of Oregon. Dr. Lewis is an associate professor in the Department of Special Education at the University of Missouri-Columbia. 
end of the continuum are definitions that focus on specific, overt behaviors or actions (e.g., saying "thank you," walking away when angry, waiting one's turn, raising one's hand for help). In between are definitions integrating the two extremes (e.g., anger management, coping, life skills, problem solving, building friendships).

For the purposes of this article, we use Gresham's definition of social competence, as it contains representative elements from the range of definitions, operates efficiently within his definition of social skills, and highlights the importance of social validation.

Social competence [is] an evaluative term based on judgments (given certain criteria) that a person has performed a task adequately. These judgments may be based on opinions of significant others (e.g., parents, teachers), comparisons to explicit criteria (e.g., number of social tasks correctly performed in relation to some criterion), or comparisons to some normative sample. (Gresham, 1986, p. 146)

\section{Social Skills}

Like the wide range of definitions for social competence, the range of definitions for social skills is broad. Some definitions focus on the expression of positive and negative feel-

\section{Focuson
exceptional children}

ISSN 0015-511X

FOCUS ON EXCEPTIONAL CHILDREN (USPS 203-360) is published monthly except June, July, and August as a service to teachers, special educators, curriculum specialists, administrators, and those concerned with the special education of exceptional children. This publication is annotated and indexed by the ERIC Clearinghouse on Handicapped and Gifted Children for publication in the monthly Current Index to Journals in Education (CIJE) and the quarterly index, Exceptional Children Education Resources (ECER). The full text of Focus on Exceptional Children is also available in the electronic versions of the Education Index. It is also available in microfilm from Xerox University Microfilms, Ann Arbor, MI. Subscription rates: Individual, \$30 per year; institutions, $\$ 40$ per year. Copyright (C) 1996, Love Publishing Company. All rights reserved. Reproduction in whole or part withou written permission is prohibited. Printed in the United States of America. Periodicals postage is paid at Denver, Colorado. POSTMASTER: Send address changes to:

$$
\begin{gathered}
\text { Love Publishing Company } \\
\text { Executive and Editorial Office } \\
\text { P.O. Box } 22353 \\
\text { Denver, Colorado } 80222 \\
\text { Telephone (303) } 757-2579
\end{gathered}
$$

Edward L. Meyen

University of Kansas
Glenn A. Vergason Georgia State University

Richard J. Whelan

University of Kansas Medical Center

Stanley F. Love

Publisher
Kristin Kennedy

Assistant Editor ings; other definitions focus on the discrete behaviors the person exhibits. For purposes of this article, social skills are "those behaviors which, within a given situation, predict important social outcomes" (Gresham, 1986, p. 5). This definition is appealing for a variety of reasons.

1. The definition emphasizes the actions or behaviors children display in their interactions with others. When focusing on behaviors, we gain greater precision in assessing and evaluating the presence or absence of a social skill and, therefore, social competence.

2. The definition includes an emphasis on the specific context or situation in which the social skill is required or used. Children and youth must become fluent at discerning the critical features of the context in which a specific social skill is required so they can discriminate what skill or skill variation is required for a successful social interaction or outcome.

3. The definition directs attention to the relationship between a given social skill and the social outcomes associated with using that social skill.

Two basic social outcomes must be considered: (a) positive peer relations/interactions, and (b) favorable adult judgments about the social skill (Gresham, 1986). The former outcome acknowledges the importance of the influence of the child's or youth's peer group in shaping and changing his or her social behavior and interactions. The latter recognizes that adults (e.g., teachers, parents, administrators, psychologists, other community people) are the ultimate judges of whether a child or youth is using appropriate social skills, especially with respect to educational decisions (e.g., instructional placements, behavior management).

\section{Social Skills Instruction}

Like definitions for social competence and social skills, definitions of social skills instruction are diverse and vary according to how the person conceptualizes social skills and social competence. Given that the main mission of the schools is seen as preparing students to become academically competent so they can become contributing members of our society, and that social skills instruction does have its conceptual variations, a more educational definition for social skills instruction is suggested. In this article, we use a definition for social skills instruction by Fuller, Lewis, and Sugai (1995): "Direct and planned instruction designed to teach specific social behavior that, when displayed by the student, results in positive judgments of social competence from peers and adults."

Social skills instruction should be "direct" in that students engage in overt behavior (e.g., verbalizations, behavioral rehearsal, written products) and teachers lead the student 
through the process in much the same way that academic facts, skills, and concepts are taught and acquired. Social skills instruction should be "planned" in that instructional sequences are prepared carefully to lead the student systematically and efficiently toward specific, planned instructional goals and objectives.

This definition aligns with the Gresham definition of social skills and considers how relevant individuals in the student's social environment judge the student's performance (Hollinger, 1987; Meadows et al., 1991). In addition, this definition assumes that social skills and social competence are acquired in ways similar to how academic skills, concepts, and competence are acquired.

\section{Assumptions}

Before discussing preferred assessment and instructional and generalization strategies, we discuss six assumptions and summary statements regarding social skills instruction (Sugai, 1990).

1. Social skills are learned behaviors and can be taught. Although some children are predisposed to learn some behaviors more readily than others because of living conditions, biophysical features, prior learning histories, and so forth, we suggest that social skills are learned responses acquired in the same manner as other skills (e.g., academic, vocational, daily living). In addition, regardless of whether social skills are considered a single response, a sequence of responses, or a collection of related responses, they are learned. Sometimes this learning is unplanned (e.g., watching the actions of others, trial and error), and sometimes it is planned (e.g., taught directly and explicitly), but in all cases children and youth can be and have been taught.

2. Behavior management problems are social skills problems. When children or youth exhibit inappropriate social behavior and fail to display appropriate social skills, we are quick to label this as a behavior management problem and to prescribe consequence-based strategies designed to eliminate the problem behavior (e.g., isolation, reprimands, restrictions, privilege loss) (Colvin, Kameenui, \& Sugai, 1993). This reactive approach fails to emphasize the importance of giving the student a suitable replacement or alternative response (i.e., social skill) that renders the inappropriate behavior less useful and effective in achieving the same outcome (Horner \& Billingsley, 1988).

A more proactive approach focuses on strengthening or teaching an effective and efficient replacement responsethat is, social skills instruction (Colvin, Sugai, \& Patching, 1993; Sugai, 1992). From this perspective, behavior problems are conceptualized as learning errors, and social skills instruction is considered an essential feature of a behavior management or an intervention plan. In the case of students with disabilities who also have identified emotional and behavioral disabilities, goals and objectives for behavior should be included on individualized education plans (IEPs).

3. Social skills are necessary prerequisites for academic skills. Social competence and academic competence are closely related and dependent. Asking permission, raising one's hand before speaking, working with peers, waiting one's turn, and seeking assistance from others are just a few of the social skills children must display to be academically successful in school settings. Many students have the opportunity to observe, practice, and receive feedback on their displays of these behaviors; however, many other students are disadvantaged in their academic teaching/learning environment because they have not learned, are not supported for displays of, or are not fluent in these academically supporting skills. Students who have not learned the prerequisite skills necessary to benefit from teacher-directed instruction, independent study, or cooperative learning activities are likely to experience academic and social failure.

4. The initial steps in setting up a social skills curriculum are time- and energy-consuming. Most teachers receive four or more years of formal preservice training, and participate in many inservice training activities throughout their teaching career. Most of this training is based on content associated with academic instruction and curriculum. Some of this time is spent on standard classroom and behavior management techniques (e.g., enforcing rules, preventing and reducing interfering behaviors, maintaining classroom order) that usually emphasize consequences. The time given to teaching social skills often is limited to describing packaged social skills programs and involving non-classroom-based resources (e.g., counselors, school psychologists, social workers, nurses).

To become competent in teaching social skills, teachers must learn about assessing and teaching social skills, practice what they have learned, and receive regular feedback on their attempts. In the best of all worlds, this training would be at the preservice and inservice levels, similar to experiences teachers receive when they learn to teach reading, science, or any other academically related skill.

Learning to implement a social skills program requires more than just reading the teacher's manual and starting with Lesson One on Monday and progressing to Lesson Two on Tuesday. For social skills to be effective and efficient, substantial time must be spent assessing individuals or groups of children; designing or modifying published curricula; planning for the integration of the social skills curriculum into other content areas and activities; assessing student progress toward specific learner outcomes; and evaluating the effectiveness of one's instructional design, materials, and implementation. A social skills program will likely fail if consider- 
ation is not given to the skills, time, and energy required to learn and implement the program.

5. The ideal curriculum does not exist. Although many curricula are instructionally sound and reasonably complete, they cannot accommodate the full range of social skills problems and social skills settings that students and teachers are likely to experience. Teachers will be required to modify or expand most of the available published curricula to meet the situation-specific needs of their students. The time invested in adapting a curricula, however, will be well spent because students will be more likely to use personally meaningful social skills, teachers will be less likely to see problem behavior at school, and peers and adults will be more likely to have rewarding interactions with students. In addition, students with disabilities who display more adaptive social skills will be viewed more positively by their nondisabled peers than students who continue to display inappropriate social behaviors (Coie, Dodge, \& Kupersmidt, 1990).

6. The approach and components of social skills instruction are fundamentally the same as academic instruction. As we have stressed, we believe that the basic instructional skills required to teach social skills are functionally the same as those used to teach academic skills. In general, when teaching academic and social skills, teachers must be efficient in how they (a) design their instruction (e.g., specify learner outcomes, assess student performance relative to expected outcomes, select and design effective instructional sequences and materials); (b) present their instruction (e.g., oral and written presentations, models, demonstrations); (c) arrange opportunities for students to practice (e.g., oral and written assignments, behavioral rehearsals); (d) assess and evaluate student learning/performance (e.g., outcome indicators, valid assessment protocols); and (e) provide informative feedback (e.g., positive reinforcement, proactive error corrections). Although the content of instruction varies, the instructional practices and techniques are the same.

\section{PREFERRED STRATEGIES FOR ASSESSING AND UNDERSTANDING SOCIAL SKILL PROBLEMS}

Successful social skills instruction is directly related to the extent to which we can conduct accurate and functional assessments (Carter \& Sugai, 1989; Haring, 1992; Lewis, 1994; Lewis \& Sugai, 1993, 1996a, 1996b; Sugai \& Fuller, 1991). Accurate and functional assessments permit us to identify who requires social skills instruction, understand problem social behaviors, identify functional replacement social skills, plan useful social skills instructional plans, and monitor and evaluate the effectiveness of these plans. If social skill information is not collected and considered in the development and implementation of social skills instruction, learning outcomes are likely to be irrelevant, ineffective, and inefficient (Horner, O’Neill, \& Flannery, 1993).

In this section we present a review of the purposes, types, and preferred methods of social skills assessment. Attention is directed to preferred, behaviorally oriented assessment practices that result in more effective and efficient instructional practices. Strategies that emphasize classification, diagnosis, and labeling outcomes are not included in this discussion.

\section{Purpose}

Social skills assessments are conducted for a number of important purposes:

1. Social skills assessments are used to screen the general social competence of individual students or groups of students. This information is used to determine generally where a social skills instructional program should begin. For example, a school has developed four rules or behavioral expectations that will be used to shape a positive schoolwide climate: (a) respect each other, (b) manage yourself, (c) work cooperatively, and (d) be safe. Each classroom teacher assesses the extent to which his or her students display behaviors that indicate they have mastered these skills. The teachers determine that most of their students have not learned the schoolwide rules and that a schoolwide social skills program should be implemented at the beginning of the school year for all students.

In a second example, a teacher screens her students to identify which students display significant social skill deficits and could benefit from an intensive social skills training program. Using criteria that identify students who display internalizing (e.g., withdrawn) and externalizing (e.g., acting out) problem behavior, the teacher selects about a fourth of the students as possible candidates for the social skills instruction.

2. Assessment strategies are used to collect information about the nature of a student's social skill problem. In general, we examine what seems to be maintaining the problem social behavior (e.g., peer/adult attention, activity escape), what kind of social skills problem the student displays (e.g., acquisition, fluency, maintenance, generalization), and what instructional strategies are likely to be most effective with a specific student or group of students. For example, a teacher learns that his student avoids social contact with peers because they tease her. When he evaluates his assessment information, he determines that the student has a limited number of appropriate social skills for responding to teasing. He develops a plan to teach the student a way to protest, a skill that results in the termination of peer teasing.

3. Social skills assessments are conducted to assist in selecting and modifying curriculum and design and delivery of instruction. Assessment information about the social skills strengths 
and weaknesses of individual students or large groups of students is used to select the most compatible, effective, and efficient social skills program (published and teacher-made). A number of important decisions can be considered. For example, are the skills that have to be taught included in a curriculum? Are teaching examples and non-examples relevant to the age/grade level and settings of the target students? Are necessary teaching strategies included, supported, and described?

For instance, a teacher determines that four of her students do not have an acceptable strategy for managing their anger. She uses this assessment information to select a published social skills program with anger and conflict management strategies. She also uses assessment information to modify the examples and non-examples found in the curriculum and to make the lessons more relevant to the students' learning histories.

4. Assessment information is used to monitor and evaluate the progress students make in their social skills instruction. This information can be used to decide whether to continue, discontinue, or change a social skills intervention. In general, evaluation information should be based on actual behavior or performance changes (i.e., what the student does) or on judgments made by others (i.e., social validation). For example, based on 5 days of assessment information a teacher notices that a student's use of a certain social skill is inaccurate, inconsistent, and deteriorating steadily. As a result, he introduces a change in the social skills instructional program, and sees an improvement in the student's performance.

\section{Assessment Methodologies}

In this section we address the purpose, outcomes, and technical adequacy of each type of assessment, shown in Table 1 , to illustrate the range of assessment types and their similarities and differences across the four purposes described in the previous section (screening, problem analysis, curriculum selection and instructional development, and progress monitoring). With respect to outcomes, two categories are differentiated. The first, behaviors and skills, refers to an emphasis on what the student does. The second category, nonbehaviors, refers to judgments, perceptions, and interpretations made by relevant others (e.g., educators, parents, peers, student). Finally we discuss broadly the technical adequacy (i.e., how much confidence we have in the assessment methods and outcomes) of each assessment type.

TABLE 1

Overview of Social Skill Assessment Types

\begin{tabular}{|c|c|c|c|c|c|c|c|c|c|}
\hline \multirow[b]{3}{*}{$\begin{array}{c}\text { SOCIAL SKILL } \\
\text { ASSESSMENT TYPE }\end{array}$} & \multirow{3}{*}{$\begin{array}{c}\text { MEASURE } \\
\text { OF } \\
\text { BEHAVIOR }\end{array}$} & \multicolumn{2}{|c|}{ OUTCOMES ${ }^{1}$} & \multirow[b]{3}{*}{$\begin{array}{l}\text { TECHNICAL } \\
\text { ADEQUACY } 2\end{array}$} & \multicolumn{5}{|c|}{ PURPOSE ${ }^{3}$} \\
\hline & & \multirow[b]{2}{*}{$\begin{array}{l}\text { Behaviors/ } \\
\text { Skills }\end{array}$} & \multirow[b]{2}{*}{ Nonbehaviors } & & \multirow[b]{2}{*}{ Screening } & \multirow[b]{2}{*}{$\begin{array}{l}\text { Problem } \\
\text { Analysis }\end{array}$} & \multirow{2}{*}{$\begin{array}{l}\text { Curriculum } \\
\text { Selection and } \\
\text { Instructional } \\
\text { Development }\end{array}$} & \multicolumn{2}{|c|}{ Progress Monitoring } \\
\hline & & & & & & & & Performance & Social \\
\hline Teacher Rankings & Indirect & Low & High & Moderate & High & Low & Low & Low & High \\
\hline Others' Ratings & Indirect & Moderate & Moderate & Moderate & High & Moderate & Moderate & Moderate & Moderate \\
\hline Peer Nominations & Indirect & Low & High & Moderate & Moderate & Low & Low & Low & High \\
\hline Self-Ratings & Indirect & Moderate & Moderate & Low & Low & Low & Low & Low & Moderate \\
\hline Behavioral Interviews & Indirect & Moderate & Moderate & Moderate & Moderate & Low & Low & Low & Low \\
\hline $\begin{array}{l}\text { Behavioral Role } \\
\text { Plays/Analogues }\end{array}$ & Indirect & Moderate & Low & Low & Moderate & Moderate & Moderate & Moderate & Moderate \\
\hline \multicolumn{10}{|l|}{ Direct Observation } \\
\hline Frequency/Tally & Direct & High & Low & High & Moderate & Moderate & Low & High & Low \\
\hline Functional Assessment & Direct & High & Low & High & Low & High & High & High & Low \\
\hline
\end{tabular}

${ }^{1} \mathrm{High} /$ moderate/low $=$ extent to which behavioral and nonbehavioral outcomes are assessed

${ }^{2} \mathrm{High} /$ moderate/low = extent to which technical adequacy is known about assessment type

${ }^{3} \mathrm{High} /$ moderate/low $=$ extent to which a specific assessment purpose is addressed 


\section{Teacher Rankings}

One of the most common types of assessment for identifying students with social skills problems and for obtaining a general perception about how students generally relate to one another is through teacher rankings. With this sociometric strategy, teachers typically rank-order their students from most to least against a specified criterion. Information about the specific behavioral strengths and weaknesses (i.e., performances) of students is not obtained through teacher rankings. For example, to identify popular and unpopular students, a classroom teacher might list students from most liked to least liked by peers. This list would be used to determine whether an all-class social skills program is needed, which smaller group of students might benefit from a social skills lesson that builds peer friendships, or to assess the effects of a social skills program.

Although easy to administer, outcome information is limited to general orderings or groupings of students and general interpretations of pre- and post-intervention effects. Gresham's (1992) review of the assessment literature indicates that "teacher rankings correspond fairly well to naturalistically observed behaviors" (p. 158), students with nonproblematic behavior often are overlooked, and evidence about the level of agreement between teachers and peers and parents is lacking.

\section{Peer Nominations}

Another sociometric method for assessing social competence involves having students nominate or rate their peers against selected criteria. These criteria tend to be nonbehavioral in form (e.g., best or worst friend, best or worst worker, least or most helpful) and focus on student's perceptions of peer acceptance/rejection or popularity/unpopularity. Like teacher rankings, peer nominations are most useful for screening and social validation (e.g., has the student become more/less popular? more/less rejected?).

Peer nomination procedures are easy to implement; however, their technical adequacies are unclear. Gresham (1992) indicates that weak correlational relationships seem to exist between positive and negative nominations and that it is unclear whether peer acceptance or peer popularity is being assessed.

\section{Ratings by Others}

Ratings by others are useful because more emphasis is placed on behavioral outcomes than broad perceptions of a child or youth's status. With this emphasis, ratings by parents, teachers, peers, and others result in information about target social behaviors, both problematic and appropriate, and social validations for nonbehavioral correlates (e.g., peer acceptance and popularity). Rating approaches usually consist of a list or collection of behavioral factors or descriptors (e.g., converses with others, makes positive self-statements, works independently, negotiates effectively with others, expresses anger appropriately) against which teachers, parents, peers, and others rate the extent to which a student displays or has those attributes (e.g., The Walker-McConnell Scale of Social Competence and School Adjustment, Walker \& McConnell, 1988). Because ratings of behavioral correlates by peers and adults correlate with other nonbehavioral sociometric tools, Gresham (1992) suggests that the assessment of social acceptance and rejection is possible.

\section{Self-Ratings}

Self-rating methods involve asking students to rate their own status (nonbehavioral) among peers (e.g., popularity, rejection, acceptance) or competence (behavioral) on specific social skills. Although appealing from a social validation perspective (i.e., how students perceive their own social competence), little evidence supports its use. Gresham (1992) indicates that, "In short, children's self-report measures have not shown to be useful in predicting peer acceptance, peer popularity, teacher rations of social skills, role-play performance, or social behavior in naturalistic settings" (p. 163).

\section{Behavioral Interviews}

Behavioral interviews are verbal (written or oral) reconstructions of behavioral events developed by students or their peers, teachers, and parents. Because these accounts are separated in time and place from actual behavioral events, the resulting information is an indirect measure of the student's social competence. Behavioral interview data, which can be behavioral or nonbehavioral in nature, are useful to define social behaviors, identify the context in which appropriate and problem social behaviors are occurring, and develop more direct observation systems and social skills interventions. Gresham's (1992) review of the research reveals relatively strong support for the use of behavioral interviews, but their utility as a method of assessing children's social competence is relatively unknown, especially how interview findings correlate with measures from teacher and peer ratings and behavioral observations.

\section{Behavioral Role Plays/Analogues}

Behavioral role plays consist of having the student practice or perform the desired social skill in an analogue (test) context to determine what the student can and cannot do under controlled conditions. Behavioral role plays are a popular method when natural opportunities to observe the student's performance are difficult to access (time, personnel, place) and infrequent. Role play assessments, however, are extremely limited in that students may know the skill and demonstrate it appropriately but continue to demonstrate inappropriate behavior in the natural setting because of com- 
peting contingencies, leading the teacher to a false conclusion that the student does not require intervention on a specific skill or set of skills (Walker, Irvin, Noell, \& Singer, 1992).

\section{Direct Observation}

Although more time and resources are required than with other assessment methods, one of the most useful means of assessing social competence is direct observation (Sugai, Maheady, \& Skouge, 1989; Walker \& Fabre, 1988). Direct observation consists of going to the "natural" setting (e.g., playground, hallway, cafeteria, bus) in which a social skills problem is occurring, noting the features of that setting, watching the student interact with others in the environment, and recording the events and the contexts in which they occur. Information might include with whom the student interacts, the nature of the interactions (e.g., socially appropriate versus inappropriate, cooperative versus antisocial), how long the interaction lasts, where the interaction occurs, what behaviors the student displays during the interaction, and so forth.

Traditional direct methods of assessment measure one or more dimension of the social skill or behavior problem of interest (i.e., frequency, duration, latency, locus, force, topography). In recent years, however, attention has centered on functional assessment procedures that examine setting, antecedent, and consequent factors that are associated predictably with specific behavioral events. These assessments target factors that trigger, predict, or maintain behavioral events. Functional assessment results are analyzed to produce hypotheses that describe possible relationships between environmental events and problem behavior and the likelihood that a behavior will occur. If these hypotheses describe the problem situation reliably, useful interventions (i.e., social skills programs) can be developed. Because of its practical utility and technical adequacy, the functional assessment technology has been identified as a preferred practice when assessing social behaviors.

Because most social skills programs are initiated in response to a pattern of inappropriate student behavior, functional assessment represents a useful method of assessing and understanding problem behavior (Lewis \& Sugai, 1993, 1996a, 1996b). Functional assessments focus our attention on the settings in which inappropriate behavior is most likely to be displayed (e.g., playground, bus, hallway). In addition, they can identify skills each child will need to be successful in targeted problem settings (Hops et al., 1985). For example, if a child has a high rate of inappropriate peer interactions at recess (e.g., derogatory name calling, pushing children, interrupting games), assessments would focus on what the child has to do instead of the inappropriate behaviors (e.g., initiate appropriate peer interactions, comply with playground rules). Functional assessments produce an estimate of the frequency or duration of both appropriate and inappropriate behaviors.
If information about comparable peer behaviors is collected, assessments can be made about the relative severity and intrusiveness of the behavioral events.

Finally, the results from functional assessments increase our understanding about what predictable outcomes (maintaining consequences) are associated with problem behaviors (e.g., escape, attention, avoidance) and what social skills (i.e., functional equivalents, fair-pair) we need to select to compete with contingencies that maintain the problem behavior.

Information from functional assessments is useful in determining the type of social problem or skill error (Lewis, Heflin, \& DiGangi, 1991; Wolery, Bailey, \& Sugai, 1988). Students who have not learned to produce or display socially correct responses (i.e., skill deficit) should be differentiated from students who have acquired appropriate social behaviors but do not display the behavior in the target setting (i.e., performance problem). This differentiation is important in determining the amount and type of instruction. A skill deficit requires direct instruction to focus on skill accuracy and fluency, whereas a performance problem requires increasing positive contingencies and practicing the skill in the target setting.

Functional assessment information also is useful in identifying teaching examples and in determining how socially competent children respond and interact under similar conditions. The examples selected should represent the range of settings and conditions under which the social skill is and is not required. These examples can assist students in determining when and where a specific social skill should be used. In addition, the examples can provide opportunities for students to learn when specific variations of a given social skill class (e.g., managing anger, initiating interactions) are and are not required for successful social interactions. Effective examples should sample and represent the full range of setting conditions, response variations, and actual versus contrived social situations. Systematically selecting and carefully sequencing effective examples combine to reduce the possibility of the student's acquiring misrules about when and under what conditions a given social skill should be used or displayed.

\section{Preferred Methods of Social Competence Assessment}

To summarize, social skills assessment information is critical for (a) a complete understanding of the nature of the social skill problem, (b) the selection of an appropriate social skill to be taught, (c) the design of an appropriate social skills lesson, (d) the selection or modification of a social skills curriculum, and (e) an adequate evaluation of the effectiveness of a social skills lesson. At a minimum, methods of social skills assessment should focus on observing the student's behaviors and his or her interactions with others. These observations should occur directly in the targeted settings and cen- 
ter on displays of appropriate and inappropriate social skills, the conditions under which the appropriate and inappropriate social skills are displayed, and the responses of socially competent students under similar social situations. To determine if the problem is a skill deficit or a performance problem, observations also should take place in settings where the student is not having social skills problems.

Because social competence is determined by relevant others in the social environment (i.e., peer acceptance and adult judgments), indirect assessment methods (e.g., interviews, rating scale) also should be used. Because the criterion for social competence varies by individual, over time, and across conditions, social perceptions from adults and peers should be collected by direct observation of actual social interactions in targeted settings. Although a student increases his or her use of conflict management skills in "nine out of 10 opportunities" (i.e., behavioral objective is achieved), success may not be realized if adults or peers identify one of 10 occurrences of the problem behavior as being unacceptable.

\section{PREFERRED INSTRUCTIONAL STRATEGIES FOR TEACHING SOCIAL SKILLS}

After assessment information has been collected and a need for teaching social skills has been determined, social skills instruction can begin. Social skills instruction is defined as direct and planned instruction designed to teach specific social behavior that, when displayed by the student, results in positive judgments of social competence from peers and adults. Like instruction involving academic, vocational, community, life, or any other type of skill, social skills instruction has five basic phases:

1. Selecting the curriculum

2. Designing the instruction

3. Preparing for presentation of instruction

4. Presenting the instruction

5. Monitoring student performance, evaluating instructional effectiveness, and modifying instruction.

Each of these phases is described briefly, followed by recommendations for preferred practice. This discussion is based on the following assumptions:

1. Teaching social skills is fundamentally the same as teaching academic skills.

2. A set of effective teaching skills has been identified.

3. Social skills instruction has to be integrated into the overall school and classroom curriculum and cannot be taught in isolation.

4. Social skills instructors must have opportunities to practice teaching social skills.
5. Assessment information is necessary to develop effective instruction in social skills and to evaluate whether social competence has been achieved.

\section{Selecting the Curriculum}

When the need to teach social skills is indicated, most teachers initially look toward published social skills curricula. A variety of published social skills training programs are available to address different age groups, social skills, teaching approaches, and settings (see Appendix for sample list). Published programs provide teachers with a basic structure from which to assess and teach social skills. These can be useful when teaching large numbers of students relatively generic social skills such as greeting others and managing stress. This sort of program also can serve as a starting point upon which to build more intensive individualized social skills plans for small groups of students or individual students who have serious social skill deficits or competing behavior problems.

Given the variety and range of available programs, selecting an appropriate social skills program is a challenging endeavor. In general, four basic questions should be considered (Cohen, Alberto, \& Troutman, 1979):

1. Who is the target population of students?

2. What is the purpose of the curriculum?

3. What are the structural and administrative features of the curriculum?

4. What methods are used to teach social skills?

Carter and Sugai $(1988,1989)$ extended these questions to include an examination of specific curricular elements:

1. What instructional components are included in the curriculum? (a) modeling, (b) strategic placement, (c) direct instruction, (d) correspondence training, (e) rehearsal/practice, (f) prompting/coaching, (g) positive reinforcement/shaping, or $(\mathrm{h})$ positive practice?

2. Are the following programming considerations covered? (a) Are assessment procedures/instruments included? (b) Is the curriculum adaptable to individual needs? (c) Can the curriculum be used with small groups? (d) Can personnel implement the curriculum without specialized training beyond that described in the curriculum? (e) Is the cost reasonable and manageable? (f) Are strategies included that will promote maintenance and generalization of skills? $(1989$, p. 38)

If a published curriculum is not selected and a teachermade curriculum is considered, the same questions should be applied. Whatever the curriculum choice, teachers must adjust the curriculum to the student's learning needs determined previously through systematic assessment. 


\section{Designing the Instruction}

As stressed throughout this article, instruction should be designed to meet the learning needs presented by the student within the context of a specifically delineated problem or target setting. In this section we present an overview of a basic approach-model-lead-test-to designing and teaching social skills and give a brief description of the key components of a complete social skills lesson.

Although variations are found across approaches to teaching social skills, instructional models of teaching and designing social skill lessons generally follow the basic model-leadtest format (Engelmann \& Carnine, 1982; Lewis, Heflin, \& DiGangi, 1991; Sugai, 1990). In general, students are presented with a demonstration of the skill to be learned (model). Next, opportunities are arranged for students to practice or rehearse the skill with assistance (e.g., verbal prompts) from the teacher (lead). Finally, students are checked to verify what they have learned and can do without assistance (test). This format of teaching social skills is generally the same as the format used to teach academic skills in a direct instruction approach.

Essential to designing social skills instruction effectively and applying the model-lead-test format is the selection and use of teaching examples. Students learn to use and not use a range of social behaviors that represent a social skill across settings from the teaching examples used during demonstration and practice activities (Engelmann \& Carnine, 1982; Scott \& Sugai, 1995). In general, the following rules (Engelmann \& Carnine, 1982; Kameenui \& Simmons, 1990) should be applied in selecting and using teaching examples to maximize opportunities for students to learn how to make discriminations in social skills:

1. Use both positive and negative examples of a social skill and the contexts in which the skill should or should not be applied.

2. Use a full range of positive and negative examples to represent social skill variations and the contexts in which the skill variations should and should not be used.

3. Sequence positive and negative examples that are minimally different to maximize discriminations about when and where a social skill should be used.

The model-lead-test format is applied within lessons that have eight major components. A brief example of a lesson designed to teach "greeting others" is illustrated in the following box, in which each of the eight major components is described briefly in relation to the example.

\section{Sample of a model-lead-test instructional lesson for teaching "greeting others."}

1. Name the skill: How to greet other students and adults.

2. Define the skill (critical rule): When you see a person you know for the first time that day, greet him (her). Ask each student to state the rule for greeting.

3. Introduce the skill components: The first thing we do when we want to greet someone is to look at the person. Second we wait for the appropriate time to speak. Third, we state our greeting.

4. Define the skill component for the day: Today we're going to talk about the rule for greeting, "When you see a person you know for the first time that day, greet him (her)."

Ask each student: "What is the rule?"

5. Demonstrate the critical rule: Set up role plays with the educational assistant in which someone wishes to greet someone.

Prompt students to observe, and following the role play, ask the students if you demonstrated the skill appropriately. Give several appropriate and inappropriate examples.

Be sure to include all students by assigning observation tasks.

\section{Practice/role play examples:}

Be sure to include all students by assigning observation tasks.

7. Test: Set up new untrained role plays for each student. Ask students to state the critical rule: "What do you do when you see someone for the first time that day?" or "What is the rule about greeting people?"; "What's the first thing to do when you want to greet someone?"

8. Assign a homework task: Tonight I want you to greet someone. Tomorrow I will ask you whom you greeted and what you said. 
1. Name of skill. Each social skill should be given a clear name or label to assist in communication during and about instruction (e.g., anger management, greeting others, initiating a conversation, accepting criticism).

2. Critical rule. Students must be taught a rule that represents discrimination about when a social skill should be or not be used. This rule includes a description of the set of conditions that occasion or signal a student to use or not use a specific social behavior. For example, the critical rule for managing anger might be "When angry, stop what you're doing and manage your anger." This rule is used to disengage the student from a problematic interaction and initiate a different response (e.g., take a deep breath, leave the situation, problem solve, manage conflict). A critical rule is used as a way for the student to learn (discriminate) when a social skill should and should not be used. The discrimination is acquired through a series of systematically sequenced positive and negative examples and the practice of a specific behavior that occasions the social skill. The acquisition and effective use of a critical rule is especially important for students who can demonstrate the social skill (e.g., four-step problem solving sequence, five-step conflict management process) in isolation but cannot or do not demonstrate the skill when it is required.

\section{Description of skill and skill components. Every social skill} lesson should include an operational (measurable, observable) description of the social skill. Depending on the student's learning history, more complex social skills may have to be broken down (task-analyzed) into smaller teaching units. For example, greeting a person might include the following steps: (a) look at the person, (b) wait for the appropriate time to speak, and (c) state your greeting. This sequence would be preceded by the critical rule for when to use the skill and would include a set of useful skill variations (Lewis, 1991b, 1992; Sugai, 1990). In our "greeting others" example, the critical rule for using the skill could be, "When you see a person for the first time that day, greet him (her)."

Skill variations are topographically different ways of engaging in the same social behavior or skill, but all serve the same function or have the same effect. For example, variations in how students greet peers and how they greet adults should be taught. Friends can be greeted with a "high-five," a friendly nickname, a facial expression, or hand gesture; whereas adults should be greeted more formally (e.g., "Good morning, Ms. Fernandez").

4. Model/demonstration. Social skill lessons should be designed to include a model/demonstration instructional activity. Modeling strategies are important but not sufficient instructional strategies for teaching social skills (Barton, 1986; Carter \& Sugai, 1988, 1989; Kratochwill \& French, 1984;
Michelson \& Mannarino, 1986). Models and demonstrations of the social skill are useful ways for students to see what the social skill and its variations look like and to learn about the conditions under which the social skill should and should not be used (i.e., critical rule). Using examples from the students' natural environment will ensure that they are culturally and age-appropriate demonstrations.

Demonstrations should be presented by individuals who are competent at the skill, are respected by the observing students, and are members of the students' normal social community (e.g., educational assistant, adult, or peer). With respect to time constraints, allow at least two examples and two nonexamples of the skill or skill component to be presented. For example, during demonstrations, appropriate (e.g., "what's up?" "уо") and inappropriate (e.g., "hey jerk," "get lost") greetings that have been observed on the playground or other common school settings also should be collected and used.

To increase the salience of the relevant features of a demonstration, teachers should describe or point out the critical features of the demonstrations as they are being presented. Descriptions can be provided by the person doing the demonstration (e.g., "Now I'm looking at the person I'd like to talk to") or by an observer (e.g., "See how she's taking a deep breath as she notices her anger rising"). In addition, before the demonstration begins, observing students should be given specific tasks to do during and after the demonstration. For example, a student might be asked to identify the conditions under which the teacher was using the anger management social skill. These kinds of assignments highlight the critical features of the social skill and the conditions under which it is required; they keep students engaged; and they teach them to focus on the important aspects of the social demonstration.

5. Role play/behavioral rehearsal. Modeling procedures are enhanced when followed by role-play or behavioral rehearsal activities in which students have the opportunity to receive guided practice (lead). Guidelines for setup, development, and selection and use of examples are the same as those used for modeling and demonstration activities. The difference is that target students are given the opportunity to practice the social skill and to receive specific feedback (reinforcement and corrective feedback) about their use of the skill.

The goal of behavioral rehearsals is to arrange opportunities for students to demonstrate the social skill in the most errorless manner possible. Initial role play attempts should be monitored closely, and students should be given early and frequent feedback about their performance. To the greatest extent possible, role plays should be orchestrated so the target student engages in the social skill successfully. If mistakes or chronic errors are expected, precorrections or reminders are useful. A precorrection is a prompt provided before and early in a problem context to minimize the occurrence of an error (Colvin, 
Sugai, \& Patching, 1993). For example, a student could be told to take a deep breath and to show the teacher what he or she will do just before the role play begins. Precorrections are designed to minimize having the student practice errors and to increase the probability of receiving positive reinforcement for appropriate display of the social skill. During role plays the target student should model or practice only positive examples of social skills. Students who have been identified as needing social skills training do not need to practice inappropriate or incorrect social behaviors; they already have demonstrated their mastery of the wrong skill!

As in modeling and demonstration activities, participants or observers can describe or point out what they are doing during the role play. Before the role play begins, nonparticipating students should be given specific tasks or activities that will engage them during the role play. For example, a nonparticipating student could be asked to prepare to report on what the target student did to greet others. Another nonparticipating student could be asked to describe the conditions under which the target student used the greeting response. Target students participating in role plays can be asked to verbalize their actions as they are practicing the social skill. The teacher can use this information to assess what is being learned and to what the student is attending.

Following the role play, teachers should focus their discussion directly on essential features of the social skill that were displayed and the conditions under which they should be displayed. To prevent students from learning misrules, irrelevant features of the role play should not be addressed. For example, after a cafeteria-greeting role play, discussions should target whether the student demonstrated the skill component of the day (e.g., "Look at the person"), not whether he or she carried a cafeteria tray or lined up appropriately. Students who display the social skill correctly during the role play and students who display approximations to the correct social skill should receive positive reinforcement. When social behavior errors are observed, proactive (informative) corrections should be provided. During discussions, common terms, phrases, and key words should be used (e.g., "That's right. Mary looked at the person when she said 'hello"”).

6. Review. To prevent students from learning isolated social behaviors and to increase exposure to the social skill, social skill lessons should allow frequent opportunities to review what has been learned. These reviews should occur within lessons, especially after demonstration and role-play activities in which social behavior components of a larger social skill are being taught in isolation. For example, "checking to see if the other person is talking" is being taught in isolation of the larger social skill of "maintaining conversations." Previous lessons should be reviewed at the beginning of each new lesson to maintain continuity. Conducting review sessions out- side the context of formal social skill lessons (e.g., at other times of the day, in other locations, during other activities) is useful to facilitate generalized responding (responding across settings, people, or times). Reviews should include opportunities for students to interact actively with the teacher by answering questions, demonstrating skills, or describing contexts in which a skill might be used or has been used.

7. Test. At the end of a social skill lesson, students should be asked to demonstrate what they have learned. This information is important for determining the extent to which a student has benefited from a lesson and the extent to which progress is being made toward mastery of the social skill (i.e., instructional objective). Tests (probes, quizzes) should consist of activities or items that have not been used in demonstrations and role-play activities. Although assessing a student's performance using test items that are identical to instructional conditions is useful for examining maintenance effects, a better indicator of generalized student responding outside the instructional context is information about the extent to which students can generalize or adapt their responses.

Depending upon the student's learning history, the complexity of the skill being taught, and the like, test items can involve oral questioning, role-play analogues, written responses, or other typical assessment strategies. Testing, however, should provide students with opportunities or simulations to engage in the actual behavior. This behavioral examination allows the teacher to see the accuracy and quality of what the student is likely to say or do. Tests should be given without precorrections or assistance because the aim of the tests is to examine the extent to which the student responds accurately and independently. After each response, corrective feedback should be given for errors. Positive reinforcement should be given for partially or totally correct responses. Testing also should occur randomly at other times of the day, in other locations, and under natural conditions to obtain a judgment of how the student might respond outside the instructional context.

8. Homework assignment. Achieving a high accuracy level in social skill performance during social skill lessons is desirable because it is an indicator of the extent to which the student is benefiting from instruction and the extent to which instruction is effective. Even so, display of the social behavior in other settings, with other people, and over time is more desirable. Assigning homework assignments is one strategy for bridging the gap between the social skill lesson, which consists of many contrived examples and activities, and the real world, which is where these social skills must ultimately be displayed.

Similar to academic instruction, homework assignments should be designed so students can practice aspects of the social skill lesson independently, successfully, and outside of the formal instructional context of the social skill lesson. Home- 
work activities should require the student to identify examples of situations in which a social skill might be used, identify the relevant features of those situations, look for correct and incorrect displays of the social skill, determine the consequences of appropriate and inappropriate use of a social skill, and practice the social skill in situations that are likely to be supportive and to provide positive reinforcement for attempts to use the social skill. Other strategies for facilitating generalized responding and response maintenance are covered next.

\section{Preparing for the Presentation of Instruction}

After social skills instruction has been designed, several logistical considerations should be considered before actually administering a social skills lesson:

1. Collect or prepare materials (e.g., curriculum, teachermade materials, other school supplies).

2. Establish a schedule and location for teaching the social skills lesson (e.g., daily, weekly; morning, afternoon; within other lessons; duration).

3. Determine group membership (minimum of two, same age versus multi-age, with or without disabilities, socially competent and incompetent).

4. Determine adult participants (e.g., teaching assistants, administrators, teachers, parents).

5. Develop and teach rules for participating in the group (e.g., attendance, on time, asking questions or requesting for assistance, getting teacher attention, consequences for rule-following and violating).

6. Teach prerequisite skills for participating in a social skills lesson (e.g., participating and observing modeling or role play activities, turning in homework assignments).

Rules for participating in the group and prerequisite skills for participating in social skills activities should be taught at the beginning of a social skills sequence and should be reviewed and reinforced regularly. In general, the same routines, rules, and structures used during other regularly scheduled academic or school lessons or activities should be followed during social skills instruction.

Preparing for the presentation of instruction also involves specifying and reviewing the behavioral objectives established for individuals or the group as a whole. A means of assessing progress toward the mastery of objectives should be developed. Using actual student performance to evaluate the effectiveness and efficiency of a social skills instructional lesson is essential. As indicated previously, student performance should be assessed during social skill lessons to determine the extent to which students are benefiting from the instruction. More important, however, is a routine for assessing student performance in natural classroom or school contexts (e.g., playground, hallways, lunchrooms) to assess the extent to which students are applying what they have learned to real social problem contexts.

\section{Presenting the Instruction}

The actual presentation of a social skills lesson should be similar to the presentation of other classroom and schoolrelated instruction. Consistent attention should be given to the rules, expectations, and routines identified and taught in the course of preparing the social skills lesson. Effective teaching strategies and practices should be implemented and monitored on an ongoing basis.

\section{Monitoring Student Performance and Implementation of Social Skills Instruction and Modifying Instruction}

Student performance should be monitored on an ongoing basis with regular cumulative review. Attention should be given to the student's actual social behavior, the effect of the student's behaviors on the environment and on the behavior of others in the environment, and the perceptions or judgments of relevant peers and adults. Because social skills are, by definition, social in nature and because social validation statements by relevant others often determine whether the student is considered socially competent, collecting information from individuals in the student's social community is important.

The most appropriate curriculum and the most perfectly designed instructional plan are only as good as the accuracy and quality of their implementation. Teachers should arrange regular opportunities to evaluate their social skills teaching practices, especially at the beginning of a social skills instructional program. A teaching colleague, supervisor, administrator, teaching assistant, parent, or other respected adult might observe the presentation of instruction and give the teacher feedback about instructional strengths and weaknesses. Alternatively, teachers can videotape themselves teaching and self-evaluate their performance later. Ultimately, one of the best indicators of the success of implementation is student performance. Students indicate their response to strong and weak assignments by the extent to which they remain actively on task, engage in disruptive or cooperative behavior, and progress toward learning and performance outcomes.

An analysis of the types of performance errors students make can indicate what adjustments have to be made in social skills instruction. In general, at least eight different instructional decisions can be made (Haring, Liberty, \& White, 1980; White \& Haring, 1980):

1. Make no change because adequate progress is indicated.

2. Change the date when instruction is expected to be completed because more or less time is needed. 
3. Slice back to a previous skill in the task analysis that was not mastered.

4. Step back to teach a missing prerequisite skill.

5. Try a different instructional strategy because the current strategy is ineffective.

6. Adjust instruction to accommodate a different phase of learning (i.e., acquisition, fluency, maintenance, generalization, adaptation).

7. Change to a new skill.

8. Implement a compliance training program to respond to interfering or competing behavior.

\section{PREFERRED PRACTICES FOR ACHIEVING GENERALIZED RESPONDING}

One of the most important and desirable outcomes of a social skills training program is generalized responding - seeing the student apply a social skill learned in one setting to another setting, with other individuals, or at a different time. Although training should continue until the student can state or demonstrate the critical rule and show the skill during social skills training, the success of a social skills training program should be judged ultimately by the extent to which students can generalize their practiced or newly learned skills to the original problem setting or context. As discussed in the introduction, social skills trained in one setting typically do not generalize beyond that setting or context (Berler, Gross, \& Drabman, 1982; Hops, Walker, \& Greenwood, 1985; Krauter, McLaughlin, \& Williams, 1986; Lewis, 1994; Lewis, Sugai , Mercer, \& Heilman, 1995; Walker, McConnell, Holmes, et al., 1983) unless training is extended to that setting or context (Kim \& Sugai, 1995; Lewis, 1994; Scott \& Lewis, 1994; Scott \& Sugai, 1995).

Although the empirical identification of effective generalization strategies is relatively sparse, some promising techniques can be employed to promote generalized responding throughout the social skills program. In this section, techniques that can be employed to increase the likelihood of generalized responding are described briefly.

\section{Selection of Relevant Examples}

Generalized responding can be facilitated by using training examples taken from the student's natural environment (Carter \& Sugai, 1989; Haring, 1992; McConnell, 1987; Steere, Pancsofar, Powell, \& Butterworth, 1989). These examples are found by conducting direct observations of target students and socially competent peers in various social situations, asking relevant others (e.g., peers, parents, teachers) about situations in which students have demonstrated social skill deficits, and interviewing target students about situations in which they have experienced problems or difficulties. By incorporating these examples into the design of social skills instruction, teachers can highlight the critical features of the contexts in which specific social skills and their variations should be used. Applying examples that have common features to relevant social situations enhances the likelihood of generalized responding.

\section{Involving Relevant Others in Training}

Including relevant staff and peers in social skills training also can help promote generalized responding (Brady et al., 1984; Scott, Himadi, \& Keane, 1983). When individuals whom students are likely to encounter in their daily routines are involved in social skills instructional activities (e.g., demonstrations, role plays), students have opportunities to become familiar with the physical and behavioral features of these social agents and to learn what to expect when they encounter these individuals outside the training context. An additional benefit of including others in social skill activities is that these individuals also are exposed to what students are being taught and can anticipate and prepare for how they might respond when they encounter the student outside the training context. These individuals can be taught to assist target students when specific social skills are needed, provide positive reinforcement when appropriate social skills are displayed, and provide positive corrections when social skill errors are made.

\section{Training in the Natural Environment}

Because the research evidence about effective generalization strategies is limited, specific interventions should be developed for direct implementation in the target generalization setting (where the student is having social behavior difficulties) (Carter \& Sugai, 1989; Chandler, Lubeck, \& Fowler, 1992; Lewis, 1994; Scott, Himadi, \& Keane, 1983). The simplest direct intervention is to prompt the student to use a targeted skill and reinforce the student in the generalized setting when an appropriate social skill is displayed (i.e., precorrection) (Chandler et al., 1992; Colvin, Kameenui, \& Sugai, 1993; Lewis, 1994). When appropriate, behavioral contracts should be used to organize the social skill expectations for the student, peers, and adults involved in the social activities of the target student. Contracts specify what social skills are expected, where and when the social skills should be displayed, and the consequences for appropriate and inappropriate social skill displays.

Other interventions that can be applied in the target problem setting and that have been shown to be effective include self-management strategies (Hops, Walker, \& Greenwood, 1988; Lewis, 1991a; Sugai \& Tindal, 1993; Wolery, Bailey, \& Sugai, 1988). Self-management strategies include selfrecording, self-selection and self-administration of consequences (positive reinforcers and punishers), and selfinstruction. Each of these strategies is designed to give the 
student a response that can be used in nontraining contexts in which the usual forms of assistance are not available but that prompt or signal the desired social skill to be displayed. Like any social behavior, self-management skills have to be taught (a) directly, (b) to a high degree of mastery to increase the likelihood that the student will use the skill, and (c) in conjunction with the social skill to be managed.

\section{CONCLUSION}

Although social skills, social skills instruction, and social competence are conceptualized differently, having and using social skills clearly are important prerequisites for success in a variety of social settings. Many students learn easily how to be successful socially across a variety of settings because their learning histories enable them to benefit from relatively informal models of learning (e.g., observation, trial-and-error learning, vicarious reinforcement). Teachers can teach social skills, but learning how to teach a social skills program requires time, effort, practice, and careful attention to detail. This article has emphasized (a) the importance of teaching social skills directly and systematically and including social skills in the classroom and school curriculum, (b) preferred strategies for assessing and understanding social skill problems, (c) preferred strategies for teaching social skills, and (d) preferred practices for achieving generalized responding.

We acknowledge the following individuals for their assistance in the preparation of this document: Rollen Fowler, Hwangyong Kim, Myounghee Kim, David Knox, Lance Schnacker, Terry Scott, and Tary Tobin. Preparation of this manuscript was supported in part by the National Center for the Improvement of Tools in Education through a grant (H180M10006) from the U. S. Department of Education, Office of Special Education Programs, Washington DC. Opinions expressed in this manuscript do not necessarily represent the position of the National Center for the Improvement of Tools in Education or the U. S. Department of Education.

\section{REFERENCES}

Asher, S. R. (1990). Recent advances in the study of peer rejection. In S. Asher \& J. Coie (Eds.), Peer rejection in childhood (pp. 3-14). New York: Cambridge University Press.

Bain, A., \& Farris, H. (1991). Teacher attitudes toward social skills training. Teacher Education \& Special Education, 14, 49-56.

Barton, E. J. (1986). Modification of children's prosocial behavior. In P. S. Strain, M. J. Guralnick, \& H. M. Walker (Eds.), Children's social behavior: Development, assessment, and modification (pp. 331-371). Orlando, FL: Academic Press.

Berler, E. S., Gross, A. M., \& Drabman, R. S. (1982). Social skills training with children: Proceed with caution. Journal of Applied Behavior Analysis, 15, 41-53.

Brady, M. P., Shores, R. E., Gunter, P., McEvoy, M. A., Fox, J. J., \& White, C. (1984). Generalization of an adolescent's social interaction behavior via multiple peers in a classroom setting.
Journal of the Association for Persons with Severe Handicaps, 9, 278-286.

Carter, J. \& Sugai, G. (1988). Teaching social skills. Teaching Exceptional Children, 20(3), 68-71.

Carter, J. \& Sugai, G. (1989). Social skills curriculum analysis. Teaching Exceptional Children, 22(1), 36-39.

Chandler, L. K., Lubeck, R. C., \& Fowler, S. A. (1992). Generalization and maintenance of preschool children's social skills: A critical review and analysis. Journal of Applied Behavior Analysis, 25, 415-428.

Cohen, S. B., Alberto, P. A., \& Troutman, A. (1979). Selecting and developing educational materials: An inquiry model. Teaching Exceptional Children, 12(1), 7-11.

Coie, J. D., Dodge, K. A., \& Kupersmidt, J. B. (1990). Peer group behavior and social status. In S. A. Asher \& J. D. Coie (Eds.), Peer rejection in childhood (pp. 17-59). New York: Cambridge University Press.

Colvin, G., Kameenui, E. J., \& Sugai, G. (1993). School-wide and classroom management: Reconceptualizing the integration and management of students with behavior problems in general education. Education \& Treatment of Children, 16, 361-381.

Colvin, G., Sugai, G., \& Patching, W. (1993). Pre-correction: An instructional strategy for managing predictable behavior problems. Intervention, 28, 143-150.

Elliott, S. N., \& Gresham, F. M. (1991). Social skills intervention guide: Practical strategies for social skills training. Circle Pines, MN: American Guidance Service.

Engelmann, S., \& Carnine, D. (1982). Theory of instruction: Principles and applications. New York: Irvington Publishers.

Fuller, M., Lewis, T. J., \& Sugai, G. (1995). Social skills instruction in schools: A survey of teachers in Oregon public schools (Behavior Disorders Research Report No. 4). Eugene: University of Oregon, Behavior Disorders Program.

Gresham, F. M. (1986). Conceptual and definitional issues in the assessment of children's social skills: Implications for classification and training. Journal of Clinical Child Psychology, 15(1), 3-15.

Gresham, F. M. (1992). Social skills and learning disabilities: Causal, concomitant, or correlational? School Psychology Review, 21, 348-360.

Haring, N. G. (1992). The context of social competence: Relations, relationships, and generalization. In S. L. Odom, S. R. McConnell, \& M. A. McEvoy (Eds.), Social competence of young children with disabilities: Issues and strategies for intervention (pp. 307-320). Baltimore: Paul H. Brookes.

Haring, N. G., Liberty, K. A., \& White, O. R. (1980). Rules for databased strategy decisions in instructional programs. In W. Sailor, B., Wilcox, \& L. Brown (Eds.), Methods of instruction for severely handicapped students (pp. 159-192). Baltimore: Paul H. Brookes.

Hollinger, D. (1987). Social skills for behaviorally disordered children as preparation for mainstreaming: Theory, practice, and new directions. Remedial \& Specific Education, 8, 17-27.

Hops, H., Finch, M., \& McConnell, S. (1985). Social skill deficits. In P. H. Bornstein \& A. E. Kazdin (Eds.), Handbook of clinical behavior therapy with children (pp. 543-598). Homewood, IL: Dorsey Press. 
Hops, H., Walker, H. M., \& Greenwood, C. R. (1988). PEERS: Procedures for establishing effective relationship skills-A program for children with socially withdrawn behaviors. Del Ray, FL: Educational Achievement Systems.

Horner, R. H., O’Neill, R. E., \& Flannery, K. B. (1993). Building effective behavior support plans from functional assessment information. In M. E. Snell (Ed.), Systematic instruction of persons with severe handicaps, 4th ed. (pp. 184-214). Columbus, $\mathrm{OH}$ : Merrill.

Kameenui, E. J., \& Simmons, D. C. (1990). Designing instructional strategies: The prevention of academic learning problems. Columbus, $\mathrm{OH}$ : Merrill.

Kratochwill, T. R., \& French, D. C. (1984). Social skills training for withdrawn children. School Psychology Review, 13, 331-337.

Krauter, R., McLaughlin, T., \& Williams, R. (1986). The effects of social skills training on mildly handicapped youngsters in the natural setting using the ACCEPTS program. B. C. Journal of Special Education, 10(3), 279-288.

Lewis, T. J. (May, 1991a). Social withdrawal assessment/intervention strategies: An investigation in maintaining treatment effects. Posterboard presentation, 17th Annual Association for Behavior Analysis: International Convention, Atlanta, GA.

Lewis, T. J. (September, 1991b). Designing effective social skills. Paper presented at Illinois Council for Children with Behavioral Disorders Conference, Chicago.

Lewis, T. (1992). Essential features of a social skills instructional program. In J. Marr, G. Tindal, \& G. Sugai (Eds.), The Oregon Conference monograph (pp. 32-40). Eugene: University of Oregon, College of Education.

Lewis, T. J. (1994). A comparative analysis of the effects of social skills training and teacher directed contingencies on the generalized social behavior of pre-school children with disabilities. Journal of Behavioral Education, 4, 267-281.

Lewis, T. J., Heflin, J, \& DiGangi, S. A. (1991). Teaching students with behavioral disorders: Basic questions and answers. Reston, VA: Council for Exceptional Children.

Lewis, T. J., \& Sugai, G. (1993). Teaching communicative alternatives to socially withdrawn behavior: An investigation in maintaining treatment effects. Journal of Behavioral Education, 3, 61-75.

Lewis, T. J., \& Sugai, G. (1996a). Functional assessment of problem behavior: A pilot investigation of the comparative and interactive effects of teacher and peer social attention on students in general education settings. School Psychology Quarterly, 11, $1-19$.

Lewis, T. J., \& Sugai, G. (1996b). Descriptive and experimental analysis of teacher and peer attention and the use of assessment based intervention to improve the pro-social behavior of a student in a general education setting. Journal of Behavioral Education, 6, 7-24.

Lewis, T., Sugai, G., Mercer, M., \& Heilman, J. (1995). An examination of reviews of social skill research: Summary of preferred practices. Eugene, OR: National Center for Improving the Tools of Educators.

Maag, J. (1989). Assessment in social skills training: Methodologi$\mathrm{cal}$ and conceptual issues for research and practice. Remedial \& Special Education, 10(4), 6-17.
McConnell, S. R. (1987). Entrapment effects and the generalization and maintenance of social skills training for elementary school students with behavioral disorders. Behavioral Disorders, 12, 252-263.

Meadows, N., Neel, R. S., Parker, G., \& Timo, K. (1991). A validation of social skills for students with behavioral disorders. $\mathrm{Be}$ havioral Disorders, 16, 200-210.

Michelson, L., \& Mannarino, A. (1986). Social skills training with children: Research and clinical application. In P. S. Strain, M. J. Guralnick, \& H. M. Walker (Eds.), Children's social behavior: Development, assessment, and modification (pp. 373-406). Orlando, FL: Academic Press.

Odom, S. L., McConnell, S. R., \& McEvoy, M. A. (1992). Peer-related social competence and its significance for young children with disabilities. In S. L. Odom, S. R. McConnell, \& M. A. McEvoy (Eds.), Social competence of young children with disabilities: Issues and strategies for intervention (pp. 3-36). Baltimore: Paul H. Brookes.

Peters, M. T., \& Heron, T. E. (1993). When the best is not good enough: An examination of best practice. Journal of Special Education, 26, 371-385.

Scott, R. R., Himadi, W., \& Keane, T. M. (1983). A review of generalization in social skills training: Suggestions for future research. In M. Hersen, R. M. Eisler, \& P. M. Miller (Eds.), Progress in behavior modification (Vol. 15, pp. 113-172). New York: Academic Press.

Scott, T. M., \& Lewis, T. J. (1994). Promoting generalized social skills among mildly disabled elementary school students. In J. Marr, G. Sugai, \& G. Tindal (Eds.), The Oregon Conference '94 monograph (pp. 121-128). Eugene: University of Oregon, College of Education.

Scott, T. M., \& Sugai, G. (1995). Facilitating generalized social interaction in children: The effects of general case instruction and reinforcement. Unpublished manuscript, University of Oregon, Eugene, Behavioral Research and Teaching.

Steere, D. E., Pancsofar, E. L., Powell, T. H., \& Butterworth, J. (1989). Enhancing instruction through general case programming. Teaching Exceptional Children, 22(1), 22-24.

Sugai, G. (1990). Social skill analysis. Unpublished manuscript. Division of Learning and Instructional Leadership, University of Oregon, Eugene.

Sugai, G. (1992). The design of instruction and the proactive management of social behavior. Learning Disabilities Forum, 17, 20-23.

Sugai, G., \& Fuller, M. (1991). A decision model for social skills curriculum analysis. Remedial \& Special Education, 12(4), 33-42.

Sugai, G., Maheady, L., \& Skouge, J. (1989). Best assessment practices for students with behavior disorders: Accommodation to cultural diversity and other individual differences. Behavior Disorders, 14, 263-278.

Sugai, G., \& Tindal, G. (1993). Effective school consultation: An interactive approach. Monterey, CA: Brooks/Cole.

Walker, H. M., \& Fabre, T. R. (1987). Assessment of behavior disorders in the school setting: Issues, problems, and strategies revisited. In N. Haring (Ed.), Assessing and managing behavior disorders (pp. 198-234). Seattle: University of Washington Press. 
Walker, H. M., Irvin, L. K., Noell, J., \& Singer, G. H. S. (1992). A construct score approach to the assessment of social competence: Rationale, technological considerations, and anticipated outcomes. Behavior Modification, 16, 448-474.

Walker, H. M., \& McConnell, S. R. (1988). The Walker-McConnell scale of social competence and school adjustment: A social skills rating scale for teachers. Austin, TX: ProEd.

Walker, H. M., McConnell, S., Holmes, D., Todis, B., Walker, J., \& Golden, N. (1983). The Walker social skills curriculum: The ACCEPTS program. Austin, TX: ProEd.

Walker, H. M., McConnell, S., Walker, J., Clarke, J., Todis, B., Cohen, G., \& Rankin, R. (1983). Initial analysis of the Accepts
Curriculum: Efficacy of instructional and behavior management procedures for improving the social adjustment of handicapped children. Analysis \& Intervention in Developmental Disabilities, 3, 105-127.

White, O. R., \& Haring, N. G. (1980). Exceptional teaching (2d ed.). Columbus, OH: Merrill.

Wolery, M., Bailey, D. B., \& Sugai, G. M. (1988). Effective teaching: Principles and procedures of applied behavior analysis with exceptional students. Boston: Allyn \& Bacon.

\section{APPENDIX: SAMPLE OF PUBLISHED SOCIAL SKILLS CURRICULUM}

Cartledge, G., \& Milburn, J. F. (1995). Teaching social skills to children: Innovative approaches ( $3 \mathrm{~d}$ ed.). Boston: Allyn \& Bacon.

Elliott, S. N., \& Gresham, F. M. (1991). Social skills intervention guide: Practical strategies for social skills training. Circle Pines, MN: American Guidance Service.

Goldstein, A. P., Sprafkin, R. P., Gershaw, M. J., \& Klein, P. (1980). Skillstreaming the adolescent: A structured learning approach to teaching prosocial skills. Champaign, IL: Research Press.

Jackson, J. F., Jackson, D. A., \& Monroe, C. (1983). Getting along with others: Teaching social effectiveness to children. Champaign, IL: Research Press.

McGinnis, E., \& Goldstein, A. P. (1984). Skillstreaming the elementary school child: A guide for teaching prosocial skills. Champaign, IL: Research Press.
McGinnis, E., \& Goldstein, A. P. (1990). Skillstreaming in early childhood. Champaign, IL: Research Press.

Schinke, S. P., \& Gilchrist, L. D. (1984). Life skills counseling with adolescents. Baltimore: University Park Press.

Stephens, T. M. (1978). Social skills in the classroom. Columbus, $\mathrm{OH}$ : Cedars Press.

Walker, H. M., McConnell, S., Holmes, D., Todis, B., Walker, J., \& Golden, N. (1983). The Walker social skills curriculum: The ACCEPTS program. Austin, TX: ProEd.

Walker, H. M., Todis, B., Holmes, D., \& Horton, G. (1983). The Walker social skills curriculum: The ACCESS program. Austin, TX: ProEd. 


\title{
IDEA Reauthorization and the Debate on Schools' Disciplinary Procedures Under IDEA
}

\author{
David Egnor
}

Beginning in May of 1995, the 104th Congress began the process of drafting legislation to reauthorize the Individuals with Disabilities Education Act (IDEA). In the spring of 1996, the Senate Committee on Labor and Human Resources unanimously passed a bipartisan bill out of committee to reauthorize IDEA. Later that summer, the U. S. House of Representatives overwhelmingly passed a bill to reauthorize the law, and it appeared that IDEA would be reauthorized for the fourth time since PL 94-142, the Education for All Handicapped Children Act of 1975, was enacted. During the final week of the 104th congressional session, however, lobbyists for the Consortium for Citizens with Disabilities (CCD), representing the interests of special education and related services professionals, children with disabilities, parents, and disability advocacy organizations, opposed the bill to reauthorize IDEA. On October 1, 1996, Senator Bill Frist, chair of the Senate Subcommittee on Disability Policy, issued a press release stating that there was insufficient time to address the outstanding concerns during the final days of the 104th Congress, and IDEA reauthorization was postponed indefinitely.

CCD lobbyists identified seven outstanding issues that led to their opposing the bill to reauthorize IDEA. Although CCD did not rank-order the seriousness of their objections, most of their criticisms were directed at proposed amendments addressing disciplinary procedures for children with disabilities. CCD raised three points of opposition regarding the proposed discipline language. These objections were the most compelling reasons for the lobbyists to oppose reauthorization of IDEA.

The remaining four issues were, briefly: (a) an amendment proposed by Congress that would have required that, in certain cases, parents notify the school district of their intent to file for due process proceedings; (b) Congress's refusal to include a new provision, proposed by lobbyists for the Council for Exceptional Children (CEC) and CCD, that would have required that related services providers attend all children's IEP meetings; (c) Congress's refusal to include a new provision that would have required that IEP teams consider five separate "special factors" when developing all children's IEPs, including whether or not children need instruction in braille or require assistive technology devices and services; and (d) a criticism that the research and teacher-training activities under IDEA were too broad-based and did not properly support categorically based personnel training and research.

This article examines the basis for CCD's opposition to IDEA reauthorization and, specifically, its role in the 104th Congress's debate regarding disciplinary procedures for children with disabilities and its subsequent opposition to amending the so-called "stay-put" provision. The article begins with an overview of the "stay-put" provision in current law, followed by a summary of the positions taken by general education and disability advocates during the most recent congressional debate on the issue. This is followed by a description of the 104th Congress's proposed amendments to the stay-put provision. The remainder of the article critiques CCD's subsequent opposition to amending the stay-put provision, followed by a discussion of the possible implications for IDEA.

\section{IDEA AND DISCIPLINARY PROCEDURES UNDER CURRENT LAW}

To ensure that children with disabilities receive access to an appropriate education, Congress provided for significant due process protections in IDEA for children with disabilities and their parents. Although the statute does not contain a specific section regarding disciplinary procedures for children with disabilities, the due process protections under IDEA contain a "stay-put" provision that is at the center of the current debate. Section 615(e)(3) of IDEA, commonly referred to as the "stay-put" provision, requires that "during the pendency of any proceedings pursuant to this section, unless the State or local educational agency and the parents or guardian otherwise agree, the child shall remain in the then-current educational placement of such child...” (20 U.S.C. §1415(e)(3)).

The seeming hard-and-fast rule, stating that the child with a disability who engages in misconduct "stays-put" in his or her then-current setting during a dispute, is given limited flexibility in the regulatory provisions under IDEA. The U.S. Department of Education's regulations adopted pursuant to the stay-put provision in the statute provide that, although the

David Egnor is a doctoral student in the Department of Special Education at the University of Kansas, and a former policy fellow with the U. S. Senate Subcommittee on Disability Policy. 
child's placement may not be changed unless the parents agree to the proposed change, "this does not preclude the school from using its normal procedures for dealing with children who are endangering themselves or others" (34 C.F.R. \$300.513). If the misconduct is not related to the student's disability, the school district may impose "normal disciplinary measures" subject to the parents' right to request a due process hearing on whether the manifestation determination was correct. In addition, the Department has noted that even if the misconduct is related to the student's disability, the student's placement can be reviewed, subject to applicable procedural safeguards under IDEA.

Many general education advocates have criticized the Department's position on the stay-put provision as inconsistent and vague. For example, the Department also holds that schools may not cease providing educational services to students with disabilities. This is so, regardless of whether the student's misconduct is determined to be a manifestation of the student's disability. Thus, though the school is given the authority to use "normal disciplinary measures" and suspend or even expel a student with a disability for misconduct not related to his or her disability, the school must continue to provide a free appropriate public education (FAPE) to that child. Despite the criticism by general education advocates, however, the Department's position is consistent with the statute and the subsequent interpretation of the statute by the U. S. Supreme Court.

In 1988, in the case of Honig v. Doe, the Court considered the issue of violence and the requirements of IDEA. The Court found that the language in IDEA is "unequivocal" and rejected the schools' argument in the case that the stay-put provision allows for the schools to remove children with disabilities unilaterally because of dangerous behavior. The Court found that "Congress very much meant to strip schools of the unilateral authority they had traditionally employed to exclude disabled students, particularly emotionally disturbed students, from school."

The Supreme Court went on to explain that this did not leave the school without a remedy. "Congress did not leave school administrators powerless to deal with dangerous students. It did, however, deny school officials their former right to 'self-help', and directed that in the future the removal of disabled students could be accomplished only with the permission of the parents or, as a last resort, the courts."

The Supreme Court also noted that the legislative history of IDEA indicated that it was enacted after finding that schools excluded one in every eight children with disabilities from classes and that Congress, by including the stay-put provision, had intended to assure the education of children with disabilities. The Court also found that Congress had carefully considered including a "dangerousness exception" to the stay-put provision but in the end had rejected that approach.
"We are not therefore at liberty to engraft onto the statute an exception Congress chose not to create," the Court wrote.

\section{SUMMARY OF THE DEBATE: SCHOOLS' DISCIPLINARY PROCEDURES UNDER IDEA}

The topic of student discipline is the most controversial issue associated with the reauthorization of IDEA since PL 94-142 was enacted. The U. S. Senate (1996) Report Accompanying the Individuals with Disabilities Education Act Amendments of 1996 stated that "The committee has attempted to strike a careful balance between the LEA's duty to ensure that school environments are safe and conducive to learning for all children, including children with disabilities, and the LEA's continuing obligation to ensure children with disabilities receive a free appropriate public education" (p. 54).

Not surprisingly, general education and disability lobbyists initially disagreed over how to strike that balance. Almost two years later, they continued to disagree over that balance. In the interim, however, consensus was reached at one point, and that temporary consensus created the discipline amendment described in this article. What immediately follows is an abbreviated, behind-the-scenes look at the consensus that grew and then dissipated-a consensus that, hopefully, will be achieved again.

\section{General Education Perspective}

The National School Boards Association (NSBA), representing local boards of education across the country, was one of the first education associations to recommend specific amendments to IDEA to address student discipline. NSBA recommended that the stay-put provision be amended to allow the school to remove a child immediately with a disability from the then-current placement if the child is believed to be a danger to self or others. Also, NSBA recommended that the school be given unilateral authority to remove a child with a disability from the classroom if the child exhibited ongoing disruptive behavior that impaired classmates' ability to learn. Moreover, it argued that students with disabilities should be held accountable for their actions using the same disciplinary procedures applied to children without disabilities, if the child's misconduct was not related to his or her disability. This accountability would include the option of ceasing educational services for children who would bring guns or possess illicit drugs on school property and the behavior is not related to their disability.

NSBA criticized the current law as having creating a "double standard" for dealing with children who are violent or disruptive. Other general education advocates quickly rallied behind NSBA's stance on violence and classroom disruption. Most notably the National Education Association (NEA), 
American Federation of Teachers (AFT), National Association of Elementary School Principals (NAESP), and National Association of Secondary School Principals (NASSP) called for revising the stay-put provision and recommended changes similar to the position taken by NSBA.

\section{Disability Lobbyists' Perspective}

The initial and pervading position taken by most disability lobbyists, on behalf of their respective organizations and children with disabilities, was threefold: (a) general education lobbyists and other advocates were exaggerating discipline problems associated with children with disabilities; (b) procedures already exist in the statute and regulations, and through legislative interpretation by the courts, for schools to deal appropriately with dangerous and disruptive children; and (c) subsequently, there was no compelling reason for Congress to amend the stay-put provision.

As evidence of their position, lobbyists pointed to the lack of statistical data supporting NSBA, NEA, AFT, and others' claims that children with disabilities were significantly endangering school safety or engaging in behaviors that significantly impaired the learning of other children. Also, they reiterated that the Supreme Court found in Honig v. Doe that IDEA did not preclude schools from seeking an injunction by the courts to remove a dangerous child from the then-current placement when the parents objected. Finally, lobbyists strongly opposed NSBA's proposal to cease providing educational services to children with disabilities in certain situations.

Although the issue of the least restrictive environment (LRE) and the inclusive schools movement surprisingly was never brought up as a factor, disability lobbyists forecast that any attempt by Congress to address the issue of discipline would lead to wholesale exclusion of children with disabilities from the public schools. In the face of a Supreme Court decision, the proported lack of systematic data demonstrating that a problem existed, and what they characterized as NSBA and other general education groups' "extremist" agendas, disability lobbyists initially opposed any changes to the stay-put provision. Instead, they advocated for more teacher training to address discipline concerns and urged Congress to increase federal funding to promote research and dissemination of model programs and practices effective in preventing and reducing of violence and disruption in public schools.

\section{Consensus Reached}

Beginning in the fall of 1995 and continuing into the early summer of 1996, congressional staff, disability lobbyists and advocates, and general education lobbyists regularly met together and separately to settle their differences and reach consensus. The first breakthrough was achieved on March 21, 1996, when the consensus group, working from a December
7, 1995, bipartisan draft amendment prepared for Senators Frist and Harkin by their respective staffs, came to a latenight agreement. Later that summer, an expanded disability and general education consensus group was formed and eventually presented Congress with a variation on the March 21 proposal, with one remaining point of contention: All disability and general education groups opposed cessation of services, with the exception of the National School Boards Association and the National Association of Elementary School Principals, who supported the option of cessation of educational services in the case of weapons and drugs.

The all-too-brief historical background serves to illustrate that the amendments to the stay-put provision described below were forged from what began as vastly divergent points of view of general education and disability advocates, to what emerged as a consensus agreement.

\section{PROPOSED CONGRESSIONAL AMENDMENTS TO THE STAY-PUT PROVISION}

Congress's recently proposed amendments to IDEA addressing schools' disciplinary procedures for children with disabilities covered four specific types of behavior, organized into two categories: (a) children whose behavior impairs the education of the child or the education of the classmates of the child and the teachers ability to teach; and (b) children who bring dangerous weapons or illicit drugs to school, and children who engage in, or are substantially likely to engage in, serious bodily injury. These proposed amendments to the current law provided exceptions to the current stay-put provision and were known collectively as the "discipline amendment." With the exception of the two categories of behavior listed above, the House and Senate bills to reauthorize IDEA maintained the current stay-put provision in all cases where the child's parents disagree with the IEP team's recommended change in placement.

\section{Seriously Disruptive Behavior}

In the case of a child with a disability whose behavior significantly impaired the education of the child or the education of the classmates of the child and the teacher's ability to teach (hereafter referred to as "seriously disruptive behavior"), the discipline amendment detailed the procedures by which the behavior could be addressed. The teacher was to call an IEP meeting and discuss the child's behavior and the appropriateness of the IEP and the services provided to the child. The IEP team was to have maintained a cumulative record over an extended time documenting the child's behavior, including documentation of efforts to address the behavior (including behavior management plans) that had been implemented over an extended time and had failed to address the child's behav- 
ior. Based on this information, if the IEP determined that the child's placement should be changed, the child could be moved to an alternative setting. If, however, the child's parents objected to the IEP team's recommended placement, the parents could call for an expedited due process hearing to review the IEP team's decision, and the child would remain in the then-current educational placement pending the decision of the hearing officer.

\section{Dangerous Weapons, Illicit Drugs, and Serious Bodily Injury}

In the case in which the child with a disability brings a dangerous weapon or illicit drugs to school, or engages in serious bodily injury against another individual, the discipline amendment proposed by Congress would give school personnel the authority to immediately order a change in the placement of the child to an appropriate alternative educational setting (selected by the IEP team) consistent with FAPE for not more than 35 school days (current law allows a child to be placed in an alternative setting for up to 45 days in the case of guns).

If the IEP team were to propose a change in the child's placement, the school would be required to notify the parents within 3 school days of that decision. Within 15 school days from the date the child is placed in the alternative educational setting, the IEP team would be required to conduct a manifestation review to determine if the behavior was related to the child's disability. The IEP team could determine that the behavior was not a manifestation of the child's disability only if the IEP team would first determine that the child's disability (a) did not impair the child's ability to understand the impact and consequences of the behavior, and (b) did not impair the child's ability to control the behavior.

If the IEP team were to determine that the child's behavior was a manifestation of the child's disability and recommend to continue the child in the alternative educational placement for the remaining 35 school days, then the child's parents could make an immediate appeal to a hearing officer to determine the appropriateness of the IEP team's decision. If the parents were in any way dissatisfied with the hearing officer's finding and the subsequent placement of the child for the remaining 35 school days, they could file a due process complaint consistent with the current law.

If the IEP team were to determine that the behavior was not a manifestation of the child's disability and recommend to continue the child in the alternative educational placement for the remaining 35 school days, the parents could file for a due process hearing consistent with the current law. During the pendency of due process or judicial proceedings, the child would remain in the alternative placement selected by the IEP team. If the school would seek to terminate educational services for children who bring dangerous weapons or illicit drugs to school and the behavior is not a manifestation of their disability, the child's case would immediately be reviewed by a hearing officer, whether the parents did or did not request a hearing, before educational services could be terminated. During the pendency of any dispute, the child was to continue to receive $\mathrm{FAPE}$ in the alternative educational setting.

\section{CCD'S OPPOSITION TO THE DISCIPLINE AMENDMENT}

During the final week of the Congress, $\mathrm{CCD}$, which initially supported the consensus discipline amendment (with the exception of schools' option to terminate services), opposed three provisions in the discipline amendment proposed by Congress. First, CCD lobbyists opposed the provisions targeted to changing the placement of children who engage in seriously disruptive behavior. CCD and other disability advocates reminded Congress that 20 years ago, children with disabilities were excluded from public schools because they were considered "too disruptive" or "unruly." They also argued that, if the stay-put provision were to be amended to include seriously disruptive behavior, Congress would be turning back the clock 20 years to wholesale exclusion of children with disabilities from public schools. Although it is unclear why the lobbyists returned to their earlier arguments as the basis for criticizing the amendments they had helped to develop, they maintained that these arguments served as compelling reasons for them to oppose the discipline amendment and the reauthorization bill.

Second, CCD opposed the provisions in the discipline amendment regarding the educational placement of the child during the time when parents are appealing a change in the child's placement. They argued that a child with a disability might be placed indefinitely in an alternative setting if the parents were to continue to appeal the IEP team's placement decision. That is, the alternative educational setting would become the stay-put placement of the child pending the resolution of the parent's appeals.

CCD misinterpreted the effect of these provisions. The child's parents could retract or suspend their complaint under section 615 of IDEA until the remaining 35 school days in the alternative educational setting had expired and the child returned to the original placement. At this time, the parents could resume their complaint, and the child would stay-put in the original placement pending resolution of the parents' complaint. Also, as discussed below, the CCD lobbyists failed to see how the pendency issue would help to resolve their third objection regarding cessation of services, and that pendency could work to the parents' advantage.

Third, and perhaps most important, CCD opposed cessation of educational services in the case of weapons and drugs when the behavior is not related to the child's disability. 
From the very beginning, the lobbyists had opposed cessation of educational services, and argued that they could not, under any circumstance, support a reauthorization bill that would allow services to be terminated for even one child with a disability. Because the cessation issue was reported to be the most compelling reason for the lobbyists to oppose the discipline amendment and the bill to reauthorize IDEA, the issue is discussed below in more detail.

\section{Cessation of Educational Services}

Despite the argument by many disability lobbyists and advocates that the proposed discipline amendment would allow for the termination of educational services for children with disabilities, the contention of this article is that educational services could not have been denied to any child with a disability. Two factors must be considered before drawing this conclusion. The first relates to the CCD lobbyists' objection regarding the pendency issue discussed above, and the right of parents to continue to object to a school's proposals under IDEA. The second factor involves the relationship between the federal, state, and local education agencies and their obligations under IDEA. References to the current law are provided so the reader may cross-reference interpretations in this section with the statutory language being referred to.

\section{Pendency and the Parental Right to Object}

The discipline amendment specified that if the parents object to the hearing officer's decision, including the school's proposal to cease educational services in the case of weapons or illicit drugs, the parents could invoke their due process rights under section 615(b) through (f) of the current law and file a complaint (thus automatically activating the stay-put provision of the current law).

Although the discipline amendment did not state directly that the child's parents could invoke the stay-put provision (section 615(e)(3)) prior to termination of educational services, the net effect was that if the child's parents would object to the school's proposal to cease educational services and they would exercise their right to appeal beyond the automatic hearing required, the child would continue to receive educational services in the alternative educational setting pending exhaustion of the parents' complaint, and the school could not terminate educational services.

The scenario, however, might not have transpired in all cases exactly as described above. For example, what if the child's parents do not object to the school's proposal to terminate services for the child, or what if the parents are not even aware they can object? And what if the parents pursue the case as far as possible and the school prevails in the end? Could educational services then be terminated for their child? To answer these questions, we must look at the relationship that exists between the federal, state, and local jurisdictions responsible for implementing IDEA.

\section{Federal, State, and Local Obligations}

Section 612 of IDEA mandates that states ensure that all children with disabilities residing in the state, between 3 and 21 years of age, are identified, located, evaluated, and receive FAPE. More specifically, section 612(1) of IDEA requires that "the State has in effect a policy that assures all children with disabilities the right to a free appropriate public education," section 612(2)(B) requires that states ensure that "a free appropriate public education [is] available for all children with disabilities," and section 612(3) requires that "the State has established priorities for providing a free appropriate public education to all children with disabilities"(20 U.S.C. §1412).

Section 614 of IDEA addresses the obligations of local education agencies (LEAs) obligations regarding the delivery of FAPE to children with disabilities. LEAs' participation, however, is not necessarily mandatory. LEAs are required to provide special education and related services only if they accept federal funds under IDEA. Corresponding state laws, however, mandate that LEAs provide FAPE to children with disabilities residing within each LEA's jurisdiction. In this way, states are able to fulfill their obligations under section 612 to ensure that all children with disabilities residing in the state receive FAPE.

If the discipline amendment described above had passed, the state still would be obligated under section 612 to ensure that all children with disabilities receive FAPE. This is so because the 104th Congress did not propose any corresponding amendment limiting states' obligations to ensure FAPE to all children with disabilities covered under IDEA. If a state were to amend the state statute subsequently to allow LEAs to terminate educational services, the state still would be obligated under section 612 of IDEA to provide FAPE to any child with a disability whose services are terminated by the LEA. In addition, section 614(d) of IDEA requires that states withhold funds from the LEA if the LEA is unable or unwilling to provide FAPE to all children with disabilities residing within its jurisdiction. If a state were to revise its statute to allow schools to terminate educational services for children with disabilities in certain cases, the state would be obligated to pull funds away from the LEA and use those funds to provide FAPE to any child with a disability whose services are terminated by the LEA.

States most likely would not intentionally put themselves in the position of pulling funds away from LEAs and becoming involved directly in providing special education and related services to children with disabilities whose services are terminated by LEAs. More likely, states would refrain from amending their state statutes and would not allow LEAs to terminate educational services in the case of weapons and illicit drugs. Moreover, states already are moving toward es- 
tablishing legislation to prohibit the termination of educational services for children without disabilities. California, for example, recently passed a law prohibiting LEAs from terminating educational services for legal residents.

The CCD lobbyists may have based their opposition to IDEA reauthorization, in part, on a misreading of the proposed discipline amendment. As illustrated above, however, the discipline amendment was somewhat convoluted, and it interacted with a number of other provisions in current law. The reader is cautioned not to judge harshly the lobbyists' apparent misinterpretation of the effects of the discipline amendment.

\section{CONCLUSIONS}

Whether the next Congress will attempt to reauthorize IDEA is unclear. There are, of course, a number of reasons why IDEA should be reauthorized. Many parents and special educators believe that the categorical nature of IDEA has led to "cookbook" IEPs based more on the child's disability label than on the child's strengths and educational needs. In addition, the discretionary authorities under IDEA expired in October of 1994 and Congress has continued to support these programs in anticipation of a bill to reauthorize IDEA. The discretionary authorities fund the research, personnel preparation, parent training and support, early intervention services (Part $\mathrm{H})$, technical assistance, and other programs and services intended to support and enhance the delivery of special education and related services to children with disabilities. Congress, however, is not likely to continue to fully fund the discretionary authorities if IDEA is not reauthorized soon.

For many reasons, IDEA may not be reauthorized. First, because Part B of IDEA is authorized permanently(including sections 612 and 614, described above), Congress does not have to reauthorize the law for services for children with disabilities to continue. Second, IDEA reauthorization has become a much more contentious undertaking than it was in the past. Previously disinterested groups now have taken a strong interest in IDEA and have raised serious concerns regarding issues of funding and procedural requirements. Any future reauthorization of IDEA will require the participation and endorsement of general education advocates.

Yet, the most recent experience with reauthorization has demonstrated to Congress that general education and disability lobbyists have been unable to maintain a consensus on IDEA reauthorization because they have not abided by their agreements with each other. One example of this is CCD's points of opposition described briefly above, where, during the final few weeks of the congressional session, the disability lobbyists began demanding that more provisions be added to the current IEP requirements, whereas general education lobbyists demanded less federal requirements. In all cases, general education and disability lobbyists focused more on what was not included in the reauthorization bill than on what they had gained (the reader is encouraged to review Egnor, 1996, for a detailed discussion of the major substantive amendments to IDEA proposed by the 104th Congress).

It is unclear if the 105th Congress will reauthorize IDEA. The debate over school disciplinary procedures for children with disabilities continues to separate general education and disability lobbyists and prevents them from reaching consensus and moving forward to reauthorize the law. Congressional members and their staffs are not immune to this split between special education and general education advocates. The rift has caused some members of Congress to conclude that little will be achieved by attempting to again reach consensus on IDEA reauthorization.

This article has attempted to provide special educators with accurate and timely information on IDEA reauthorization so people in the field can make informed choices on how to proceed with any future reauthorization. In view of the information available at the time of this writing, it seems unlikely that IDEA will be reauthorized unless we as special educators are able to settle some of the differences we have with general educators and reach consensus on critical issues, particularly the stay-put provision. If we are unable to do so, we may do a disservice to ourselves and to children with disabilities.

\section{REFERENCES}

Education for All Handicapped Children Act of 1975, 20 U.S.C. § 1400 et seq.

Egnor, D. E. (1996). Individuals with Disabilities Education Act Amendments of 1996: Overview of the U. S. Senate bill (S.1578). Focus on Autism and Other Developmental Disabilities, 11(4).

Honig v. Doe, 484 U.S. 305, 323 (1988).

Individuals with Disabilities Education Act of 1990, 20 U.S.C. § 1400 et seq.

U. S. Department of Education, Office of Special Education Programs, Policy Letter, 20 IDELR 542 (1993).

U. S. Senate, Committee on Labor and Human Resources. (1996). Report accompanying the Individuals with Disabilities Education Act Amendments of 1996. (S. Rept. No. 104-275). 


\section{Teaching Special Learners in the General Education Classroom Methods and Techniques-Second Edition

\author{
Kathleen McCoy \\ Arizona State University
}

Responsive to supporting the inclusion of special students in the general education classroom, this second edition of a popular book for teaching special children in the general education classroom helps teachers understand children with disabilities and provides effective instructional strategies. Packed with ideas for managing and organizing classroom time, it includes instructional tips and suggestions. Multicultural concerns and technology are addressed in a way that helps teachers get the job done for the maximum benefit of all the children.

\section{Features}

- Covers planning, assessment, and groups

- Addresses all of the inclusion issues

- Shows intervention methods and techniques

- Presents vignettes to personalize each situation

\section{Contents}

1. A Modern Fable

2. Mainstreaming and Inclusion Movements

3. Children with Mild to Moderate Learning Problems

4. Children with Physical, Visual, and Hearing Disabilities

5. The Individualized Education Program

6. Classroom Organization

7. Pinpointing Reading Skills

8. Reading Methods
- Responds to all sides of the major issues

- This book has personality and will appeal to the general education classroom teacher

- Glossary
9. Reading for Special Populations
10. Language Arts Stephen Isaacson
11. Mathematics Skills Evaluation
12. Mathematics Instruction Virginia Usnick and Kathleen McCoy
13. Accommodation Through Technology: Personal Computers

\section{LOVE PUBLISHING COMPANY \\ 1777 South Bellaire Street \\ Denver, CO 80222 \\ 303-757-2579•Fax 303-782-5683}




\section{Professional update}

Learning Disabilities Association of America

February 19-22, 1997

Palmer House Hotel

Chicago, Illinois

Contact: Learning Disabilities Association of America 4156 Library Rd.

Pittsburgh, PA 15234

\section{Canadian Council for Exceptional Children}

February 26-28, 1997

Winnipeg, Manitoba

Contact: Gavin Scott

177 Oak Street

Winnipeg, MB R3M 3P7

Telephone: 204-453-46 31

\section{National Association of School Psychologists}

April 1-5, 1997

Anaheim Hilton Hotel

Anaheim, California

Contact: National Association of School Psychologists 4340 East West Highway

Suite 402

Bethesda, MD 20814

\section{Council for Exceptional Children}

April 9-13, 1997

Annual Conference

Salt Lake City, Utah

Contact: Council for Exceptional Children 1920 Association Drive Reston, VA 22091

\section{The China - U.S. Conference on Education}

July 9-13, 1997

Beijing, People's Republic of China

This will be the largest gathering of Chinese and American educators ever assembled. Conference cost is $\$ 2,850$ for a nineday Conference Program Package including international airfare, meals, lodging, conference fees, cultural and historic sites in Beijing. Also available are study programs to other cities, a demonstration learning center, and school partnerships. For detailed information on the Conference contact:

Global Interactions, Inc.

Department GC-97

14 West Cheryl Drive

Phoenix, AZ 85021

Telephone: 602-943-3922

Fax: 602-943-4458 